\title{
Web-Based Implementation of Risk Analysis of Paddy Production with ENSO Indicators
}

\author{
Nisa Miftachurohmah, Imam Mukhlash, and Sutikno
}

\begin{abstract}
In Indonesia, paddy production depends heavily on the amount of rainfall. Thus, there needs to be a risk analysis for paddy production by utilizing rainfall data patterns. However, since much rainfall data is missing then we use the ENSO indicator which is anomaly SST 3.4. In the previous research, the results of software design include analysis of the relationship between paddy harvest area and anomaly of SST 3.4 by using Copula and estimation model design of paddy harvest area using Robust regression. This research implements the prediction model of harvested area based on ENSO indicators into a web-based software. The results of this harvested area model will be used to predict paddy production. Furthermore, the prediction of rice production is compared with the amount of rice consumption of the population to obtain the level of risk of paddy production. Thematic maps are used to present the risk level of paddy production.
\end{abstract}

Index Terms-Decision Support System (DSS), ENSO, copula, robust regression.

\section{INTRODUCTION}

East Java province has the highest level of paddy productivity compared to other provinces in Indonesia. Based on data from BPS, from 2000 to 2013 the level of paddy productivity is always unstable, even a decline in several years. One reason is the lack of knowledge about production risk management. One of the factors that influence paddy production is seasonal changes caused by climate change. Seasonal changes sometimes do not fit the cycle, this is influenced by the existence of climate disturbances [1]. Climate disturbance associated with rainfall cause agricultural activity to be disturbed, especially paddy.

ENSO associated with climate forecasts can be useful for agricultural decision-making [2]. A risk assessment framework developed to evaluate the climate uncertainty associated with agricultural output comes from a model that can be used for policy decision-making [3].

Agricultural products (food and horticulture) are very dependent on climate conditions. ENSO is one of the most important indicators of seasonal climate variability in the world. Some previous studies have shown a correlation between yields and ENSO [4].

Manuscript received September 9, 2018; revised April 16, 2019.

Nisa Miftachurohmah is with the Information System Department, Universitas Sembilanbelas November Kolaka, Indonesia (e-mail: nisa.informatics@gmail.com).

Imam Mukhlash is with the Mathematics Department, Institut Teknologi Sepuluh Nopember Surabaya, Indonesia (e-mail: imammukhlash@gmail.com).

Sutikno is with the Statistics Department, Institut Teknologi Sepuluh Nopember Surabaya, Indonesia (e-mail: tikno@yahoo.com).
In paddy production management, Mukhlash et.al. have developed spatial decision support systems for paddy production risk levels in East Java [5]. In the same location but with a different approach, Oktaviana et al. has conducted research about the vulnerability of rice puso with ENSO indicators [6]. Miftachurohmah et al. have designed a software architecture to risk analysis of paddy production in East Java with ENSO indicators [7]. In 2004, Falcon et al. used climate models to improve food security in Indonesia. The research is related to the Naylor study that integrates climate knowledge, risk assessment and analyzes policies using ENSO in Indonesia [3].

Several other studies have also applied ENSO in agriculture. The impact of ENSO on paddy production has been investigated in several countries, including China [8] and Philippines [9]. Whereas in Sri Lanka, the relationship between ENSO and seasonal paddy production can be used for agriculture policy management and formula [10]. Furthermore, there is a climate forecast information system with an ENSO indicator for agricultural risk management in the southeastern United States [11].

The spatial and temporal patterns of wheat fields in Australia and relates them to ENSO [12]. Lagos and Buizer in [4] show that estimation of growing cotton and rice production with El-Nino higher yields than without El-Nino forecasts. In addition, Podesta et al. in [4] suggests an increase in maize and sorghum production during the ElNino phase and decreased production during the La-Nina phase in Pampas Argentina (central-east Argentina). Model of Paddy Harvest and Rainfall Anomaly in Bojonegoro District with Robust LTS Approach [13]. The ENSO phase is also used as an indicator to increase wheat production in Paraguay [14]. In 2015, Anisa and Sutikno [15] proposed a pattern of rainfall relationship and ENSO indicator in East Java.

Based on this background, there is a need to study to analyze the risk level of paddy production with ENSO indicator. This study is expected to produce paddy risk levels in accordance with ENSO data on a monthly basis each year (short term).

\section{PRELIMINARIES}

\section{A. Data Set}

This study uses SST 3.4 anomaly data as an ENSO indicator. The historical data of the ENSO indicator was obtained from the National Oceanic and Atmospheric Administration (NOAA) and the ENSO indicator prediction data was obtained from The Predictive Ocean Atmosphere Model for Australia (POAMA); data on harvested area and productivity of paddy obtained from Central Bureau of 
Statistics and Agricultural Service of East Java Province.

\section{B. Research Stages}

The stages of the research carried out consist of: define response and predictor variable; identify the relationship of predictor variables and response variables using Copula Correlation; prepare a prediction model or paddy harvest area for each sub-round using OLS and robust regression approach; determine the prediction of paddy production based on the harvest area model results and determining the level of risk of paddy production based on the level of production and population needs; modeling to DSS component for paddy production risk level and integrating estimation process, determining risk level and representation of thematic map on DSS.

A detailed explanation of the steps above is as follows:

1) Define response and predictor variable

The response and predictor variables used in this study are as follows:

$X=$ Predictor variable, in this case is the SST 3.4 anomaly which is an ENSO indicator.

$Y=$ Response variable, in this case is the area of paddy harvest.

\section{2) Identify the relationship of predictor variables and} response variables using Copula Correlation

The steps to identify the relationship of predictor variables and response variables using Copula Correlation can be seen in Fig. 1.

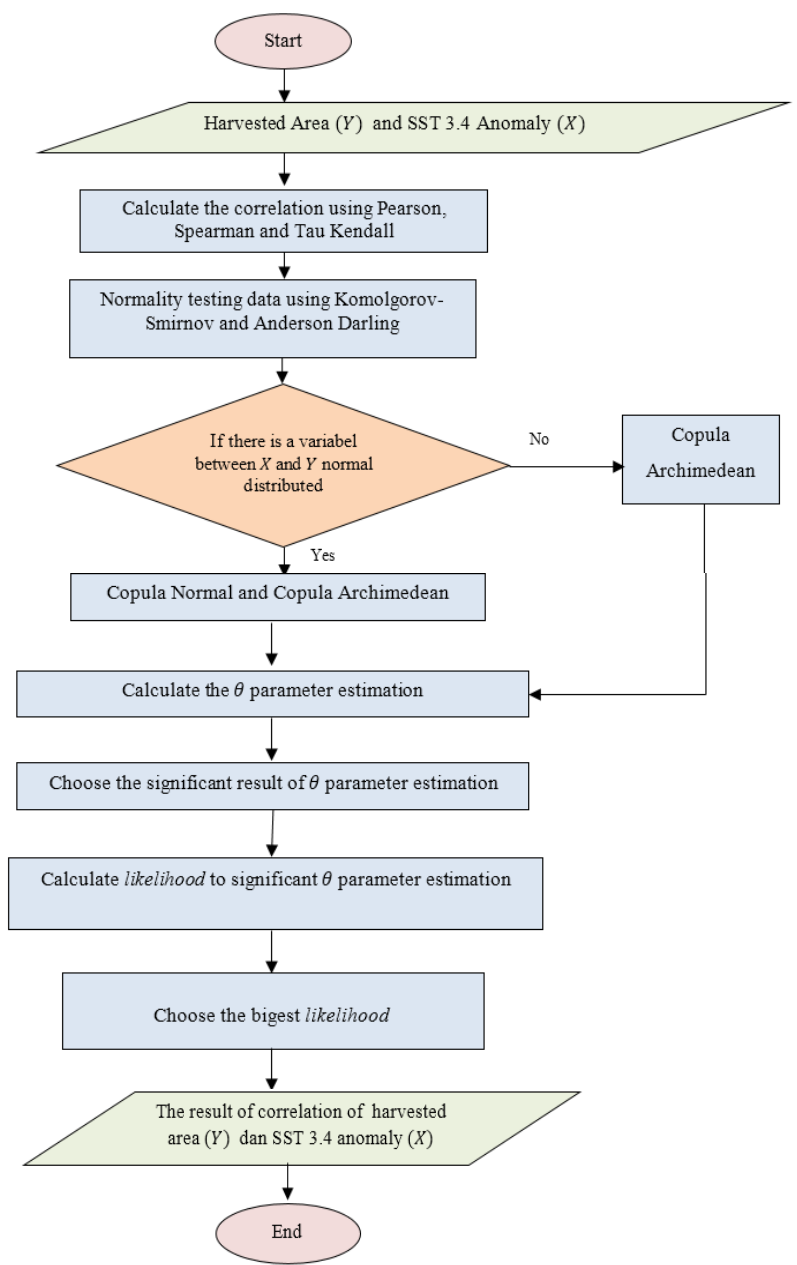

Fig. 1. Flowchart to identify the relationship of predictor variables and response variables using Copula Correlation.
Estimation of $\theta$ of Copula Archimedean can be seen at Table I.

TABLE I: ESTIMATION OF PARAMETER OF COPULA ARCHIMEDEAN [16]

\begin{tabular}{cc}
\hline Copula & Estimation $\hat{\theta}$ \\
\hline Clayton & $\hat{\tau}=\frac{\theta_{c}}{\theta_{c}+2}$ maka $\hat{\theta}_{c}=\frac{2 \hat{\tau}}{1-\hat{\tau}}$ \\
\hline Gumbel & $\hat{\tau}=1-\frac{1}{\theta_{G}}$ maka $\hat{\theta}_{G}=\frac{1}{1-\hat{\tau}}$ \\
Frank & $\hat{\tau}=1-\frac{4\left(1-D_{1}\left(\hat{\theta}_{F}\right)\right)}{\hat{\theta}_{F}}$ \\
& with $D_{k}(x)=\operatorname{Debye~function~}^{x} \int_{k}(x)=\frac{k}{x_{k}} \int_{0}^{e^{u}-1} d u$ \\
\hline
\end{tabular}

3) Prepare a prediction model or paddy harvest area for each sub-round using OLS and robust regression approach

The steps to modeling of harvested area of paddy using OLS approach is depicted in Fig. 2.

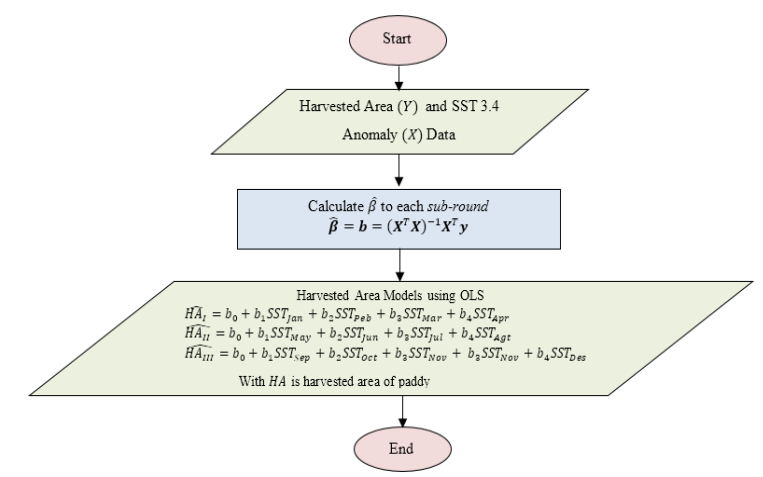

Fig. 2. Flowchart to modeling harvested area of paddy using OLS approach.

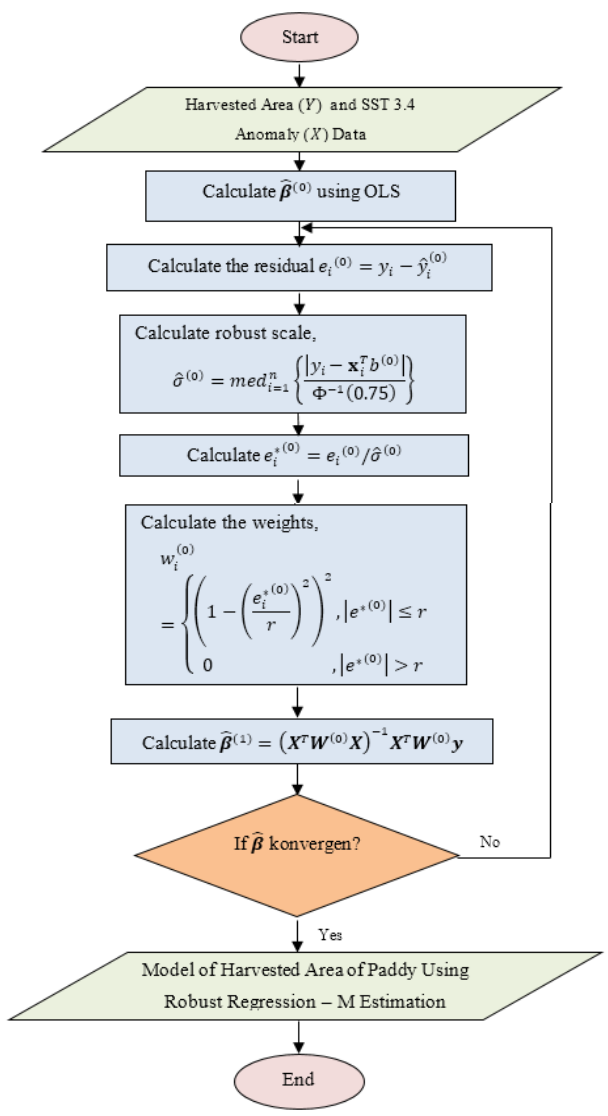

Fig. 3. Flowchart of modeling harvested area of paddy using robust regression approach. 
After the model of harvested area of paddy obtained, the model is used as input of robust regression approach. The steps to modelling of harvested area of paddy can be seen in Fig. 3.

The harvested area prediction model is used to calculate the predicted area of harvest. Therefore, it is necessary to select the best harvested area model between the OLS model and the robust regression for each sub-round in 5 districts. The selection of the best model is to calculate the residual or error of each model of harvested area and then selected the smallest residual amount.

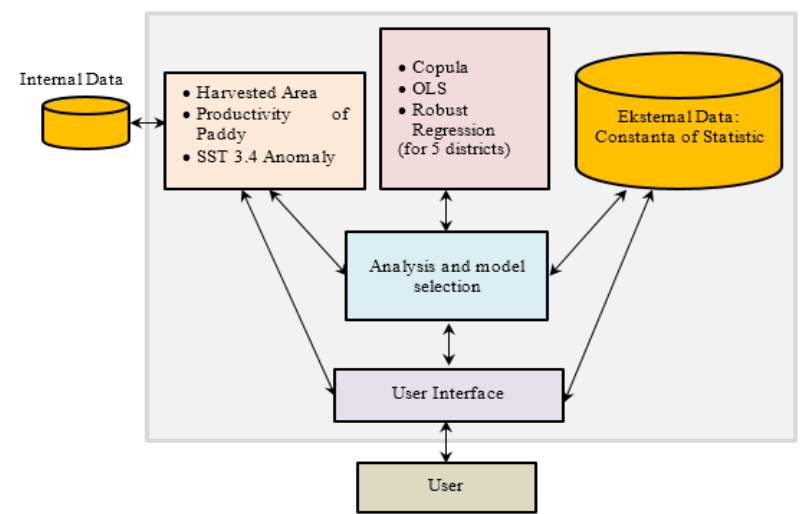

Fig. 4. The DSS model of web-based of paddy production risk level.

4) Determine the prediction of paddy production based on the harvest area model results and determining the level of risk of paddy production based on the level of production and population needs

Harvest area prediction is used to calculate production prediction by equation:

$$
\text { Production }_{i}=\text { Harvested }_{\text {Area }_{i}} . \text { Productivity }_{i}
$$

with $i=I, I I$ dan $I I I$ which is a sub-round of paddy production.

The determination of paddy production risk level is determined based on the need or consumption of paddy derived from paddy by the population in each district. The yield of paddy production is equivalent to the production of dry milled grain (DMG). Therefore, it is necessary to first convert from paddy to rice. Here are the steps to obtain the level of risk of paddy production: conversion from DMG to rice, average shrinkage from paddy to rice by $37.26 \%$ (Central Bureau of Statistics, 2015), so that rice as inventory can be obtained equation.

$$
\text { Stock }_{i}=\text { Production } \times 62.74 \%
$$

With $i=I, I I$ dan $I I I$ which is a sub-round of paddy production.

Then calculate the need or consumption of rice for each district. Based on data from Central Bureau of Statistics (2015), the consumption of paddy per month per capita is $6.8 \mathrm{~kg}$. Thus, the equality of paddy demand for each district is obtained.

$$
\text { Needs }=\frac{6.8}{1000} \times \text { Total Population }
$$

Finally, the determination of risk level of paddy production with the following conditions:

$$
\text { Risk Level }= \begin{cases}\text { High, } & \text { Stock }_{\mathrm{i}}<\text { Needs } \\ \text { Low, } & \text { Stock }_{\mathrm{i}}>\text { Needs }\end{cases}
$$

with $i=I, I I$ dan $I I I$ which is a sub-round of paddy production.

5) Modeling to DSS component for paddy production risk level and integrating estimation process, determining risk level and representation of thematic map on DSS

The DSS model of web-based of paddy production risk level can be seen in Fig. 4.

\section{RESUlt AND ANALYSIS}

A. Results of Correlation to Harvested Area of Paddy and SST 3.4 Anomaly using Copula.

The result of $\theta$ Copula parameter can be seen in Fig. 5. The parameters $\theta$ Copula Archimedean (Frank, Clayton and Gumbel) were obtained from the calculation of equation depicted in Table I, while the $\theta$ Copula Normal parameter was obtained from the Pearson approach.

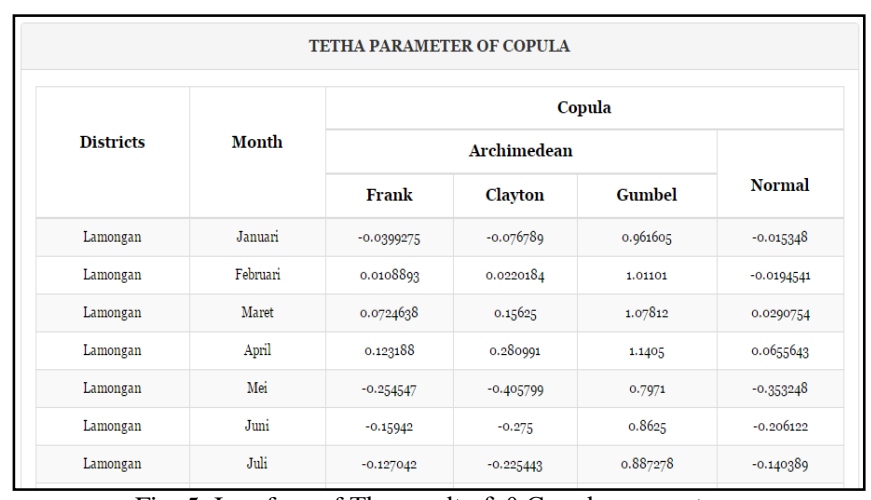

Fig. 5. Interface of The result of $\theta$ Copula parameter.

TABLE II: THE RESUlt OF CORRELATION BETWEEN HAREVESTED AREA OF PADDY AND SST 3.4 ANOMALY

\begin{tabular}{lll}
\hline \hline Districts & Month & Copula \\
\hline \multirow{3}{*}{ Lamongan } & May & Frank \\
& October & Clayton \\
& November & Clayton \\
& December & Normal \\
\hline \multirow{5}{*}{ Ngawi } & May & Normal \\
& June & Normal \\
& October & Normal \\
\cline { 2 - 3 } & November & Clayton \\
& December & Normal \\
\hline \multirow{5}{*}{ Banyuwangi } & January & Normal \\
& May & Normal \\
& September & Normal \\
& October & Normal \\
& November & Normal \\
& December & Normal \\
\hline \multirow{2}{*}{ Jember } & January & Normal \\
& February & Normal \\
& March & Normal \\
& May & Normal \\
Bojonegoro & November & Normal \\
& December & Normal \\
\hline \multirow{2}{*}{} & Jaye & Normal \\
& & Normal \\
\hline
\end{tabular}

The result of calculation of parameter estimation $\theta$ Copula (in Fig. 5) show that each of sub-round harvest area in five districts have significant result or in other words $\mathrm{p}$ value $<\alpha$, for $\alpha<0.05$, in sub-round 2 and sub-round 3 . 
Pattern of harvest area 5 regency and anomaly SST 3.4 has a relationship that follows more than one type of Copula. Therefore, Copula fitting or the best Copula selection using Maximum Likelihood Estimation (MLE) was calculated using software $\mathrm{R}$. The decision for the best relationship pattern of each pair of variables was selected based on the result of fitting with significant $\mathrm{p}$-value and the greatest value of log-likelihood.

Most of the results of correlations of harvested area and SST 3.4 anomalies follow Copula Normal are presented in Table II.

\section{B. Model of Harvested Area of Paddy}

The model for estimation of harvested area is a linear model with SST 3.4 anomaly as the predictor variable. The parameter estimation model used OLS model and robust regression. Estimation of harvested area model parameters with OLS for each district can be seen in Table III.

Parameter estimation using OLS is the first step for calculating parameter estimation using robust regression. The result of parameter estimation of harvested area model using robust regression for each district is shown in Table IV.

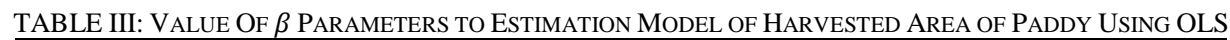

\begin{tabular}{llrrrrr}
\hline Districts & Harvested Area & b0 & b1 & b2 & b3 & b4 \\
\hline \multirow{3}{*}{ Lamongan } & Subround 1 & 64678 & 2008 & -16073 & 15269 & 4482 \\
& Subround 2 & 40022 & -8370 & 2208 & -1597 & 524 \\
& Subround 3 & 11830 & -2722 & -5726 & 6184 & -765 \\
\hline \multirow{3}{*}{ Ngawi } & Subround 1 & 40352 & 7003 & -14342 & 4595 & 3705 \\
& Subround 2 & 37073 & -1312 & -9430 & 6149 & -2217 \\
& Subround 3 & 15303 & 8977 & -22480 & 19370 & -8116 \\
\hline \multirow{3}{*}{ Banyuwangi } & Subround 1 & 49963 & -4623 & -18704 & 29197 & 89 \\
& Subround 2 & 27742 & -4698 & 1327 & -2081 & -2318 \\
& Subround 3 & 30351 & -123 & -2557 & -8713 & 6622 \\
\hline \multirow{3}{*}{ Bojonegorony } & Subround 1 & 64083 & -8096 & -3712 & 14558 & -545 \\
& Subround 2 & 30609 & -13417 & 16934 & -11897 & -3941 \\
& Subround 3 & 7862 & -1110 & -13173 & 14098 & -3190 \\
\hline \multirow{3}{*}{ Jember } & Subround 1 & 69703 & 4420 & -21083 & 20733 & -1126 \\
& Subround 2 & 49627 & -812 & -7806 & 9598 & -7237 \\
& Subround 3 & 18830 & -1765 & -2426 & 7062 & -4404 \\
\hline \hline
\end{tabular}

\begin{tabular}{|c|c|c|c|c|c|c|}
\hline Districts & Harvested Area & b0 & b1 & b2 & $\overline{\text { b3 }}$ & $\overline{\text { b4 }}$ \\
\hline \multirow[t]{3}{*}{ Lamongan } & Subround 1 & 66703.5 & -9343.3 & 3408.79 & 8905.82 & 2515.94 \\
\hline & Subround 2 & 40041.5 & -8522.4 & 2935.64 & -2199.38 & 650.741 \\
\hline & Subround 3 & 11442 & 2128.78 & -6529.3 & 1598.53 & 1276.81 \\
\hline \multirow{3}{*}{ Ngawi } & Subround 1 & 41860.3 & -1409.9 & 817.212 & -1083.84 & 2433.9 \\
\hline & Subround 2 & 37259.2 & -1666.1 & -8145.8 & 4949.48 & -1678.56 \\
\hline & Subround 3 & 14431.3 & 9753.5 & -9776.4 & 10235.2 & -9179.08 \\
\hline \multirow{3}{*}{ Banyuwangi } & Subround 1 & 52553.8 & -7602.4 & -4267 & 13482.8 & 3001.43 \\
\hline & Subround 2 & 27900 & -4778 & 1332.56 & -2186.21 & -1876.65 \\
\hline & Subround 3 & 31324.4 & 506.77 & -4534.3 & -2027.12 & 2745.18 \\
\hline \multirow{3}{*}{ Bojonegoro } & Subround 1 & 66635.2 & -19683 & 19438.6 & 3048.94 & -1190.96 \\
\hline & Subround 2 & 30522.1 & -13459 & 16982 & -12195.3 & -3765.52 \\
\hline & Subround 3 & 7814.17 & -670.65 & -12259 & 12707.3 & -2817.06 \\
\hline \multirow{3}{*}{ Jember } & Subround 1 & 72269.8 & -7920.8 & 648.207 & 13552.9 & -4024.53 \\
\hline & Subround 2 & 49829.7 & -2645.3 & 1447.64 & 1742.86 & -5169.68 \\
\hline & Subround 3 & 18486.3 & -871.61 & -2312.1 & 4924.75 & -2697.35 \\
\hline
\end{tabular}

TABLE V: The Best Model SElEction of HARVESTEd AREa OF PADDY

\begin{tabular}{llrrl}
\hline \multirow{2}{*}{ Districts } & Sub & \multicolumn{2}{c}{ The Residual Amounts } & Model \\
\cline { 3 - 4 } & Round & OLS & Robust & Selection \\
\hline \multirow{2}{*}{ Lamongan } & 1 & 130997 & 107961 & Robust \\
& 2 & 189100 & 187794 & Robust \\
& 3 & 77907.8 & 76530.9 & Robust \\
\hline \multirow{2}{*}{ Ngawi } & 1 & 86259.2 & 68381.2 & Robust \\
& 2 & 112380 & 109127 & Robust \\
& 3 & 109595 & 105330 & Robust \\
\hline \multirow{3}{*}{ Banyuwangi } & 1 & 145794 & 130053 & Robust \\
& 2 & 131884 & 132199 & OLS \\
& 3 & 89716.1 & 83969.5 & Robust \\
\hline \multirow{2}{*}{ Bojonegoro } & 1 & 153068 & 137805 & Robust \\
& 2 & 270471 & 269317 & Robust \\
& 3 & 64832.9 & 64593.9 & Robust \\
\hline \multirow{2}{*}{ Jember } & 1 & 142290 & 106533 & Robust \\
& 2 & 133918 & 132025 & Robust \\
& 3 & 50563.9 & 50591.7 & OLS \\
\hline
\end{tabular}

The residual amounts of each model (OLS and Robust Regression) are compared to select the best model, which has the lowest residual. The best model selection of harvested area of paddy depicted in Table V.

The calculation data in Table $\mathrm{V}$ shows that most of the best harvested area models with the smallest number of residuals use robust regression models. Moreover, some of the best harvested area models with the smallest residual number use OLS models.

\section{Prediction of Paddy Production}

Calculation of predicted paddy production is derived from the results of the predicted harvested area with the best harvested area model. Paddy yield is equivalent to dry milled grain (DMG) of paddy. The conversion of DMG to rice is used as the inventory, and then the inventory is used to determine the risk level of production.

The DMG conversion to rice depicted in Fig. 6, and it shows that the conversion from DMG to rice has decreased by $37.26 \%$. Most predictions of rice production in each district always decrease from subround 1 to subround 2, 
then decrease again in subround 3. However, the prediction of rice production in Banyuwangi District increases from subround 1 to subround 2, then decreases in subround 3 .

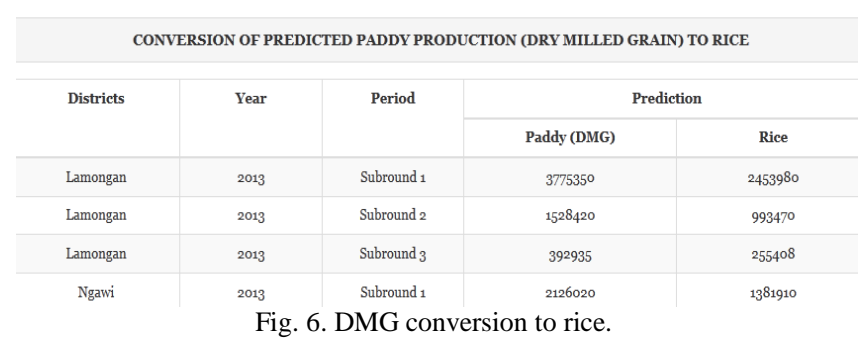

\section{Risk Prediction of Paddy Production}

The amount of rice consumption of the population in each district as input to calculate the level of risk of paddy production.

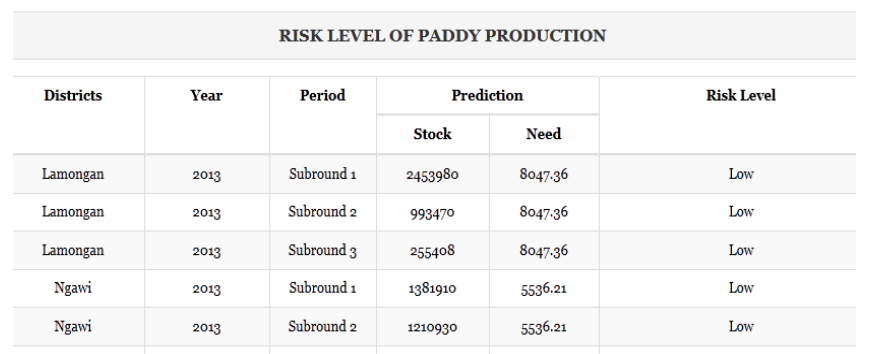

Fig. 7. Result of risk prediction of paddy production.

Risk Level of Paddy Production

Subround I: January - April 2015

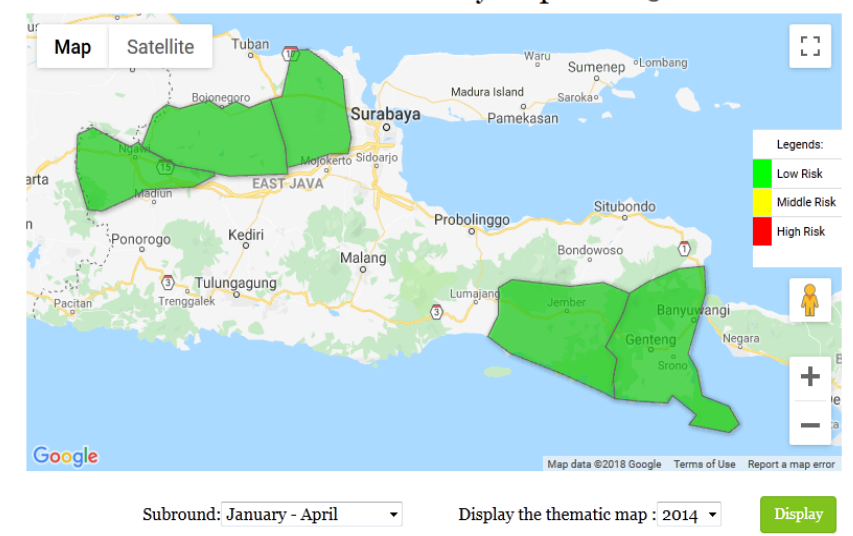

Fig. 8. The thematic map of risk prediction of paddy production.

If the amount of rice supply is less than the rice consumption needs, the risk level is high. If the amount of rice supply is more than the rice consumption needs, the risk level is low.

The results of the predicted risk level of paddy production can be seen in Fig. 7. In this study, shows that the results of the predicted risk level of paddy in each district have low risk level. This is because the prediction of rice production growth rate is greater than the rate of population growth. In addition, these five districts are the centers of rice production in East Java.

Finally, the results of predicted risk level are transformed to the thematic map of the future risk level of paddy production, which is depicted in Fig. 8. The color of all of the five districts polygon are green. This means that the predicted risk level of paddy production has low risk level.

\section{CONCLUSION AND FUTURE WORK}

In this paper we have discussed the implementation of a web-based decision support system for predicting the risk of rice production. System components consist of model components (Copula, OLS and Robust Regression), data (SST anomaly 3.4 and rice harvest area) and interfaces. The prediction process initially by determining the correlation between rice harvest area and SST 3.4 anomaly, modeling the area of harvest and rice production, and then determining the level of risk of rice production.

Based on the simulation results show that:

1) The correlations between paddy harvestedarea of 5 districts in East Java are well identified using Copula Normal. This is due to SST 3.4 anomaly data and harvest area data has a normal distribution.

2) The predicted harvested area models of each district were obtained using OLS, as input to determine the predicted harvested area model using Robust Regression.

3) The best models for the predicted harvested area model in each district is using Robust Regression

4) The predicted risk level of paddy production based on rice consumption of population in each districts has low risk level.

The future work of this research is integrating this application into a decision support system for determining the risk of rice production containing short and long-term predictions.

\section{ACKNOWLEDGEMENT}

We would like to thank The Ministry of Research, Technology, and Higher Education of Republic of Indonesia to support this research with contract number 900/PKS/ITS/2018.

\section{REFERENCES}

[1] H. Mulyanti, "Effect of El-Nino/Southern Oscillation (ENSO) Against Monthly Rainfall in Java Island," S. Si. Theses, Dept. Geography, Universitas Gajah Mada, Yogyakarta, 2012.

[2] G. Podestá, D. Letson, C. Messina, F. Royce et al., "Use of ENSOrelated climate information in agricultural decision making in Argentina: A pilot experience," Agricultural Systems, vol. 74, no. 3, pp. 371-392, December 2002.

[3] R. L. Naylor, et al. (2009). Agricultural decision-making with ENSO Variability: Integrating climate science, risk management, and policy analysis. Freeman Spogli Institute for International Studies at Stanford University. [Online]. Available: http://www.researchgate.net/publication/252433538_Agricultural_De cision_Making_In_Indonesia_With_ENSO_Variability_Integrating_ Climate_Science_Risk_Assessment_And_Policy_Analysis

[4] V. E. Cabrera, "Managing climate risks to agriculture: Evidence from El-Nino," Southeast Climate Consortium Technical Report Series, 2009.

[5] I. Mukhlash, R. Maulidiyah, Sutikno, and B. Setiyono, 2017, "Webbased decision support system to predict risk level of long term rice production," in Proc. IOP Conf. Series: Journal of Physics: Conf. Series, IOP Publishing, 2017.

[6] P. P. Oktaviana, Sutikno, and H. Kuswanto, "Copula approach to develop insecurity maps of Puso paddy in east java using ENSO indicators," Final Project, Department of Statistics, Institut Teknologi Sepuluh Nopember Surabaya.

[7] N. Miftachurohmah., I. Mukhlash, and Sutikno, 2015, "Software design to risk analysis of paddy production with ENSO indicators (case-study; east java)," in Proc. International Conference on Researh, Implementation and Education of Mathematics and Sciences, 2015, Yogyakarta State University, 17-19 May, 2015.

[8] D. Xiangzheng et al., "Impact of El nino-southern oscillation events on China's paddy production," Journal of Geographical Sciences, vol. 20, pp. 3-16. 
[9] M. G. Roberts et al., "El-Nino Southern Oscillation Impacts on Paddy Production in Luzon, Philipines," Journal of Applied Meteorology and Climatology, vol. 48, pp. 1718-1724, 2008.

[10] L. Zubair, "El nino-southern oscillation influences on paddy production in Sri Lanka," Intenational Journal of Climatology, vol. 22, pp. 249-266, 2002.

[11] C. W. Fraisse et al., "AgClimate: A Climate forecast information sistem for agricultural risk management in the southeastern USA," Computers and Electronics in Agriculture, vol. 53, pp. 13-27, 2006.

[12] A. B. Potgeiter, G. L Hammer, and D. Butler, "Spatial and temporal patterns in Australian wheat yield and their relationship with ENSO," Australian Journal of Agricultural Research, vol. 53, pp. 77-89, 2002.

[13] J. R. Budiani, Sutikno, and P. Purhadi, "Analisis hubungan dan pemodelan luas panen padi dengan indikator El-Nino Southern Oscillation (Enso) Di kabupaten bojonegoro melalui pendekatan copula dan regresi robust m-estimation," Jurnal Sains dan Seni ITS vol. 4, issue 2, pp. D127-D132, 2015.

[14] M. A. Ramires-Rodrigues et al., "Tailoring wheat management to enso phases for increased wheat production in paraguay," Climate Risk Management, vol. 3, pp. 24-38, 2014.

[15] K. N. Anisa and Sutikno, 2015, "analisis hubungan curah hujan dan indikator el-nino southern oscillation di sentra produksi padi jawa timur dengan pendekatan copula," Jurnal Sains dan Seni ITS, vol. 4, issue 1, pp. D49-D54.

[16] J. Fox. (2002). Robust regression, appendix to An R and S-PLUS companion to applied regression. [Online]. Available: http://cran.rproject.org/doc/...Companion/appendix-robust-regression.pdf

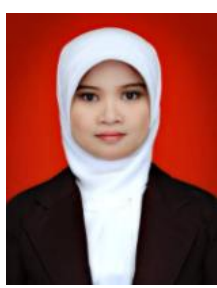

N. Miftachurohmah is currently a lecturer at Universitas Sembilanbelas November Kolaka, she received master dgree in mathematics from Institut Teknologi Sepuluh Nopember Surabaya, in 2015; and bachelor degree in informatics engineering from Universitas Islam Negeri Malang, in 2011. Her current research includes data mining and DSS.

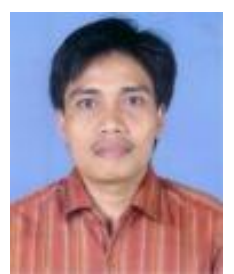

I. Mukhlash is a lecturer in the Department of Mathematics, Faculty of Mathematics, Computing, and Data Sciences, Institut Teknologi Sepuluh Nopember, Indonesia. He received his B.Sc. in mathematics from Institut Teknologi Sepuluh Nopember, a master degree and a doctoral degree both in informatics from Institut Teknologi Bandung, Indonesia. His research interests include data mining, fuzzy logic, intelligent systems, and decision support systems. He has been awarded some grant research projects such as from Institute of Research and Public Services, Institut Teknologi Sepuluh Nopember and National Research Program, the Ministry of Research, Technology, and Higher Education of Indonesia. He has published many papers in international journal and conferences.

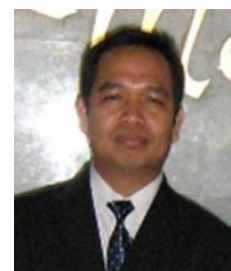

Sutikno is a lecturer at the Department of Statistics, Institut Teknologi Sepuluh Nopember Surabaya. He received his master and bachelor degree in statistics from Institut Teknologi Sepuluh Nopember Surabaya, in 2002 and 1996, respectively; and doctoral degree from Institut Pertanian Bogor, in 2008. His current research includes climatology modeling and spatial statistics. 